\title{
PHYTOREMEDIATION OF FLUORIDE-CONTAMINATED WATER BY Landoltia punctata
}

\author{
Amanda F. Braga ${ }^{1}$, Alisson C. Borges ${ }^{1 *}$, Lucas R. L. Vaz ${ }^{1}$, \\ Tamara D. de Souza², André P. Rosa ${ }^{1}$ \\ ${ }^{1 *}$ Corresponding author. Federal University of Viçosa/ Viçosa - MG, Brazil. \\ E-mail: borges@ufv.br| ORCID ID: https://orcid.org/0000-0002-9729-6439
}

\section{KEYWORDS}

duckweed, fluoride, central composite design, phytoextraction.

\begin{abstract}
Fluorine is released into the water environment naturally or by anthropogenic activities. Fluorine promotes health benefits at low concentrations, but it promotes adverse effects ranging from fluorosis to carcinogenic problems at high concentrations. Although fluorine removal from environment can occur through processes such as adsorption, reverse osmosis, and electrodialysis, the phytoremediation emerges as an accessible and environmentally friendly treatment. This research aimed to study the phytoremediation potential of Landoltia punctata for treating water contaminated with fluorine ion (fluoride). The central composite rotatable design was used to assess the effect of three variables in the process: $\mathrm{pH}$ ranging from 5 to 9 ; phosphate concentration from 0 to $10 \mathrm{mg} \mathrm{L}^{-1}$; and nitrate concentration from 0 to $800 \mathrm{mg} \mathrm{L}^{-1}$. The plants were exposed to a fluoride initial concentration of $5 \mathrm{mg} \mathrm{L}^{-1}$ in $3 \mathrm{~L}$-vessels that also included Clark's solution for a period of 10 days. Experimentally, removal of up to $21 \%$ was observed for the supplied fluoride. Values of the order of $30 \%$ for the removed fluoride mass can be predicted by the obtained model. Landoltia punctata is a promising candidate for the phytoremediation of fluoride-contaminated waters.
\end{abstract}

\section{INTRODUCTION}

Fluorine has been widely studied, as it is a highly reactive element, being the $13^{\text {th }}$ most abundant element in the environment (Kanduti et al., 2016). Fluorine can be introduced into the environment mainly by biogeochemical processes, i.e., weathering of rocks and minerals and anthropogenic activities such as industrial wastewaters and residues, pesticides, and fertilizers (Banerjee, 2015; Abouleish, 2016).

Fluorine concentrations can cause beneficial or harmful effects, depending on the ingested concentration. Reduced levels at around 0.8 to $1.0 \mathrm{mg}$ $\mathrm{L}^{-1}$ can prevent cavities, normal bone mineralization, and formation of tooth enamel (Barathi et al., 2019). However, chronic exposure to high fluorine doses has been related in several studies with neurotoxic, carcinogenic, and genotoxic effects, as well as diseases such as dental or skeletal fluorosis. Reduction in fertility and function of the thyroid gland has also been identified (Ghaderpoori et al., 2018; Qasemi et al., 2019; Štepec \& Ponikvar-svet, 2019).

The World Health Organization (WHO) recommends a maximum concentration of $1.5 \mathrm{mg} \mathrm{L}^{-1}$ of fluoride $\left(\mathrm{F}^{-}\right)$for drinking water, but more than 260 million people worldwide are estimated to be exposed to concentrations higher than this value (Banerjee, 2015). In Brazil, there is a high incidence of fluorosis, as shown by the data compiled by Sari et al. (2004). It was reported some serious scenarios at locations supplied by groundwater where more than $80 \%$ of the local population seemed to be affected by the consumption of water containing up to $21 \mathrm{mg} \mathrm{L}^{-1}$ of fluoride. Data collected in Brazilian's states capitals from 2010 to 2013 and presented in the

\footnotetext{
${ }^{1}$ Federal University of Viçosa/ Viçosa - MG, Brazil.

${ }^{2}$ Federal University of Ouro Preto/ Ouro Preto - MG, Brazil.

Area Editor: Marcelo Bortoli

Received in: 4-3-2020

Accepted in: $12-17-2020$
} 
Epidemiological Bulletin of the Brazilian Ministry of Health (2015) showed that $1.6 \%$ of the samples (total of 305,448 samples) taken from the water treatment outlet and $10.5 \%$ of the samples (total of 62,648 samples) of the distribution network were out of the established standard (>1.5 $\left.\mathrm{mg} \mathrm{L}^{-1}\right)$. Macapá, Fortaleza, Aracaju, and Florianópolis stood out as the states capitals with the highest percentage of samples with fluoride contents above recommended values.

Several techniques can allow the treatment of fluoride-contaminated waters, such as adsorption, precipitation, electrodialysis, and membranes. However, these techniques present high costs and waste generation to be disposed and treated (Singh et al., 2016). Thus, phytoremediation emerges as an alternative treatment, as it is ecologically sustainable and cheaper compared to traditional techniques, as well as be widely used in contaminated areas (Dubchak \& Bondar, 2018; Ikeura et al., 2016).

Many plants can absorb contaminants from the environment, including fluoride. The selection of tolerant and resistant species is essential for the success of phytoremediation (Weerasooriyagedara et al., 2020). The main conditions that influence fluoride absorption are solution $\mathrm{pH}, \mathrm{F}^{-}$concentration, chemical form of fluorine, plant species, and the presence of other elements, such as calcium, aluminum, and phosphorus (Baunthiyal \& Ranghar, 2014; Singh et al., 2018).

Some authors attempt to elucidate the effects in the plants due to contact time and fluoride concentration. Sinha et al. (2000) reported maximum efficiency after 7 days of contact for the aquatic plant Hydrilla verticillata. Karmakar et al. (2018) observed a growing fluoride absorption rate in the first 4 days for the aquatic species Pistia stratiotes, being stabilised after 8 days. Absorption was negligible after the 10th day.

Among the several determining factors for phytoremediation processes, the screening of plant species is the focus of intense research (Díaz \& Pedraza, 2010; Khandare et al., 2017). Plant performance is assessed by removal efficiency, kinetics, tolerance index, growth rate (Sokolova et al., 2019; Yadav et al., 2018), and physiological disturbances that interfere with chlorophyll content, proteins, and enzymes (Karmakar et al., 2016). However, no reports were found regarding the influence of nutrient levels typical of eutrophic environments (nitrogen and phosphorus) in the phytoremediation of waters with high amounts of fluoride.

According to Pereira et al. (2016), Landoltia punctata is "a small angiosperm, with floating fronds, ovate to lanceolate, flattened, slightly asymmetrical at the base, with green color, smooth edge, usually purplish red". The species has a fast growth rate and the capacity to develop in wastewater, thus being a candidate for the phytoremediation processes (Stegemeier et al., 2017). The literature indicates that L. punctata is a species with a great capacity to bioaccumulate arsenic, nickel, zinc, and uranium (Nie et al., 2017) and petroleum hydrocarbons (Ertekin et al., 2015). In this context, this study aimed to assess fluoride mitigation by the species $L$. punctata when submitted to different values of phosphate, nitrate, and $\mathrm{pH}$.

\section{MATERIAL AND METHODS}

\section{Obtaining and acclimating plants}

The aquatic species L. punctata, belonging to the subfamily Lemnoideae and family Araceae, were collected in the botanical garden of the Federal University of Viçosa $\left(20^{\circ} 45^{\prime} 37^{\prime \prime} \mathrm{S}\right.$ and $\left.42^{\circ} 52^{\prime} 04^{\prime \prime} \mathrm{W}\right)$, sanitized and acclimatized for three months in polyethylene vessels with 10 liters of Clark's nutrient solution (Clark, 1975) and pH 6.5. Clark's nutrient solution was modified regarding nitrogen and phosphorus levels, being renewed weekly. The plants were maintained at room temperature and controlled artificial light, without direct sunlight and under a photoperiod of 16 hours of light for 8 hours of darkness controlled by a timer. The lighting support had white tube fluorescent lamps $(32 \times 1212 \mathrm{~mm}, 40 \mathrm{~W}$, and $2650 \mathrm{~lm}$ ) maintained at $60 \mathrm{~cm}$ from the support bench of vessels. Environmental conditions (control of lightness and air temperature) were maintained during the experimental period. The experiment was carried out in April, when the temperature in the city of Viçosa has an average value of $20.3{ }^{\circ} \mathrm{C}$, not exceeding $26.1^{\circ} \mathrm{C}$.

\section{Experimental design and conditions}

The central composite rotatable design (CCRD) was used as the statistical design for the experiment. This method requires a smaller number of treatments than the full factorial design and it can be performed sequentially to achieve optimization. Contour lines were generated with the observed results, as well as models that describe the response variable according to the results observed in the analysis of variance. The less significant variables were eliminated from these models according to the hierarchical level (Mateus et al., 2008).

The fluoride removal efficiency was used as a dependent variable. The following independent variables were chosen after literature review and preliminary tests: $\mathrm{pH}$, as the chemical balance of fluorine species in solution, more or less preferred for absorption, depends on the pH (Ruan et al., 2004); nitrogen concentration, in the form of nitrate, and phosphorus concentration, in the form of phosphate, since these macronutrients are highly available in the environment and wastewaters (Kim et al., 2012), N and $\mathrm{P}$ interfere with plant growth and development (Linkohr et al., 2002; Mantai \& Newton, 1982; Stevens et al., 1998).

Thus, the design was composed of three independent variables $\left(2^{3}\right)$, including four replications at the central point and six axial points, totaling 18 tests. Levels were tested in a wide range aiming at the prospect of the optimum point. The $-\alpha$ values for nitrate and phosphate were set to zero to act also as a control. The $+\alpha$ values were higher than those found in the literature, seeking to create an extreme situation. Table 1 shows the values used in the central composite rotatable design. 
TABLE 1. Values of $\mathrm{pH}$, phosphate, and nitrate concentrations used in the central composite rotatable design according to the experimental region adopted for the test.

\begin{tabular}{ccccccc}
\hline Variable & Code & $\boldsymbol{\alpha}=-\mathbf{1 . 6 8}$ & $-\mathbf{1}$ & $\mathbf{0}$ & $\mathbf{+ 1}$ & $\boldsymbol{\alpha}=+\mathbf{1 . 6 8}$ \\
\hline $\mathrm{pH}$ & $\mathrm{X}_{1}$ & 5 & 5.8 & 7 & 8.2 & 9 \\
Phosphate $\left(\mathrm{mg} \mathrm{L}^{-1}\right)$ & $\mathrm{X}_{2}$ & 0 & 2.0 & 5 & 8.0 & 10 \\
Nitrate $\left(\mathrm{mg} \mathrm{L}^{-1}\right)$ & $\mathrm{X}_{3}$ & 0 & 162.2 & 400 & 637.8 & 800 \\
\hline
\end{tabular}

*Nitrate and phosphate values do not refer to the corresponding $\mathrm{N}$ and $\mathrm{P}$, but the anionic groups.

The tests were carried out in polyethylene vessels with an average diameter of $25 \mathrm{~cm}$ and a water depth of $7.75 \mathrm{~cm}$ containing three liters of modified Clark's solution (Clark, 1975). Nitrate and phosphate concentrations were adjusted according to the tests described in Table 1, and supplied with calcium salts $\left(\mathrm{Ca}\left(\mathrm{NO}_{3}\right)_{2} \cdot 4 \mathrm{H}_{2} \mathrm{O}\right.$ and $\left.\mathrm{Ca}\left(\mathrm{H}_{2} \mathrm{PO}_{4}\right)_{2} \mathrm{H}_{2} \mathrm{O}\right)$. The extra supply for treatments that needed nitrate and phosphate amounts higher than those recommended by Clark's solution was performed using sodium salts $\left(\mathrm{NaNO}_{3}\right.$ and $\left.\mathrm{NaH}_{2} \mathrm{PO}_{4}\right)$ in order not to exceed the calcium concentrations. In contrast, treatments with concentrations lower than Clark's solution for these two nutrients had their calcium amounts compensated with calcium acetate. Thus, variations in the recipe occurred only for nitrate and phosphate, while other nutrients required for the development and survival of plants had their concentrations followed. The $\mathrm{pH}$ values were adjusted with hydrochloric acid and sodium hydroxide.

The plants were exposed to a concentration of 5 $\mathrm{mg} \mathrm{L}^{-1}$ of fluoride, added as sodium fluoride $(\mathrm{NaF})$ at the beginning of the experiment for 10 days. At the end of this period, the analyses of fluoride $\left(4500-\mathrm{F}^{-} \mathrm{C}\right), \mathrm{pH}$ $\left(4500-\mathrm{H}^{+} \mathrm{B}\right)$, and nitrate $\left(4500-\mathrm{NO}_{3}{ }^{-} \mathrm{C}\right)$ were performed according to Standard Methods for the Examination of Water and Wastewater (APHA, 2017) and phosphate according to Murphy \& Riley (1962). The plant mass increase (wet basis) was registered as well as average evapotranspiration by determining the volume difference in each vessel after the 10 days.

All treatments started with $2 \mathrm{~g}$ of plant biomass (wet basis), which were free to occupy the entire vessel surface. The plants were harvested from the acclimatization trays, washed with distilled water, left on paper towels for 1 hour to remove excess water, and then weighed and placed in the vessels of the experiment. The same procedure was carried out at the end of the experiment to ascertain the final wet mass.
After measuring the final wet mass, L. punctata plants were placed in glass beakers and taken to the oven at $105^{\circ} \mathrm{C}$ for 48 hours. The masses were measured again after drying to obtain the final dry mass.

\section{Fluoride determination}

Aliquots of the solutions of each test were collected with a pipette after homogenization for analysis on $10^{\text {th }}$ day, and their removals were counted in the final $\mathrm{F}^{-}$calculation of each test. Fluoride was measured using the $4500-\mathrm{F}^{-} \mathrm{C}$ method (APHA, 2017), using a selective electrode. The selective fluoride electrode is solid-state and based on a lanthanum fluoride monocrystal $\left(\mathrm{LaF}_{3}\right)$. The reference electrode consists of $\mathrm{Ag} / \mathrm{AgCl}$ with a double junction, with an external solution of $10 \% \mathrm{w} / \mathrm{v} \mathrm{NaNO}_{3}$ and an internal solution of $3 \mathrm{~mol} \mathrm{~L}^{-1} \mathrm{KCl}$ saturated with $\mathrm{AgCl}$. An aliquot of $10 \mathrm{~mL}$ of sample and $10 \mathrm{~mL}$ of total ionic strength adjustment buffer (TISAB) were added to a volumetric flask of $100 \mathrm{~mL}$ to read the samples. The volume was completed with distilled water, homogenized, and poured into a beaker for measurement under magnetic stirring. The electrodes (selective ion and reference) were inserted into the samples and the results were obtained in millivolts. The conversion of millivolts into fluoride concentration in $\mathrm{mg} \mathrm{L}^{-1}$ was performed using calibration curves $\left(\mathrm{R}^{2}>99 \%\right)$. Mass balance calculations were performed from the observed concentrations considering the evapotranspiration that occurred in each treatment. Thus, the final results were obtained in removed fluoride mass.

\section{RESULTS AND DISCUSSION}

Table 2 shows the values of $\mathrm{pH}$, initial phosphate and nitrate concentrations, dry mass of plants, and the percentage of fluoride removal from the aqueous medium. 
TABLE 2. Initial ( $\mathrm{pH}$, nitrate, and phosphate) and final (plant mass and removed $\mathrm{F}^{-}$) conditions of the experiment.

\begin{tabular}{cccccc}
\hline & \multicolumn{3}{c}{ Independent variable } & \multicolumn{2}{c}{ Dependent variable } \\
\hline Test & Initial pH & $\begin{array}{c}\text { Initial phosphate } \\
\left(\mathrm{mg} \mathrm{L}^{-1}\right)\end{array}$ & $\begin{array}{c}\text { Initial nitrate } \\
\left(\mathrm{mg} \mathrm{L}^{-1}\right)\end{array}$ & $\begin{array}{c}\text { Final mass of dry plant } \\
(\mathrm{g})\end{array}$ & $\begin{array}{c}\text { Removed } \mathrm{F}^{-} \\
(\%)\end{array}$ \\
\hline 1 & $\mathbf{5 . 8}$ & 2.0 & 162.2 & 0.22 & 15.1 \\
2 & $\mathbf{8 . 2}$ & 2.0 & 162.2 & 0.21 & 9.4 \\
3 & $\mathbf{5 . 8}$ & 8.0 & 162.2 & 0.22 & 15.9 \\
4 & $\mathbf{8 . 2}$ & 8.0 & 162.2 & 0.22 & 12.2 \\
5 & $\mathbf{5 . 8}$ & 2.0 & 637.8 & 0.26 & 4.0 \\
6 & $\mathbf{8 . 2}$ & 2.0 & 637.8 & 0.36 & 11.5 \\
7 & $\mathbf{5 . 8}$ & 8.0 & 637.8 & 0.27 & 10.0 \\
8 & $\mathbf{8 . 2}$ & 8.0 & 637.8 & 0.31 & 19.5 \\
9 & $\mathbf{5 . 0}$ & 5.0 & 400.0 & 0.18 & 7.2 \\
10 & $\mathbf{9 . 0}$ & 5.0 & 400.0 & 0.30 & 21.0 \\
11 & $\mathbf{7 . 0}$ & 0.0 & 400.0 & 0.27 & 16.3 \\
12 & $\mathbf{7 . 0}$ & 10.0 & 400.0 & 0.36 & 14.0 \\
13 & $\mathbf{7 . 0}$ & 5.0 & 0.0 & 0.37 & 12.9 \\
14 & $\mathbf{7 . 0}$ & 5.0 & 800.0 & 0.25 & 9.2 \\
15 & $\mathbf{7 . 0}$ & 5.0 & 400.0 & 0.32 & 11.7 \\
16 & $\mathbf{7 . 0}$ & 5.0 & 400.0 & 0.38 & 11.2 \\
17 & $\mathbf{7 . 0}$ & 5.0 & 400.0 & 0.31 & 11.6 \\
18 & $\mathbf{7 . 0}$ & 5.0 & 400.0 & 0.45 &
\end{tabular}

Average general removal of $12.1 \%$ of $\mathrm{F}^{-}$was observed after the 10-day period, considering all the tests, while the average referring to replicates at the central point was $10.9 \%$. The maximum removals were observed in tests $10(21.0 \%)$ and $8(19.5 \%)$. Overall, the highest $\mathrm{F}$ - removals were obtained in basic $\mathrm{pH}$ (average of $14.7 \%$ ) while the lowest (average of $8.9 \%$ ) were those corresponding to the five tests with the lowest supplied phosphate concentration. The dry mass of plants measured at the end of the experiments showed no observable trend. On the other hand, an average increase of $66.7 \%$ was observed in the biomass of plants (wet basis), though no significant difference between treatments was seen. The plants multiplied at the end of the experiment, occupying the entire surface area of the vessel. No signs of necrosis were observed with the naked eye.
The statistical analysis of the data showed that the different levels of $\mathrm{pH}\left(\mathrm{X}_{1}\right)$, phosphate $\left(\mathrm{X}_{2}\right)$, and nitrate $\left(\mathrm{X}_{3}\right)$ interfered with the fluoride removal from the aqueous medium. The removal was attributed to absorption by $L$. punctata although no analyses were performed on the plant tissue. In part, some fluoride precipitation may have occurred although this phenomenon has not been observed in previous studies under similar conditions for Lemna valdiviana, a species from the same subfamily as L. punctata (Silva et al., 2019). The significance of each variable can be observed in the Pareto charts at 1, 5, and $10 \%$ significance levels. The results can be verified considering the natural response (removal efficiency, Figure 1a) and the transformed response (square root of removal efficiency, Figure 1b). 


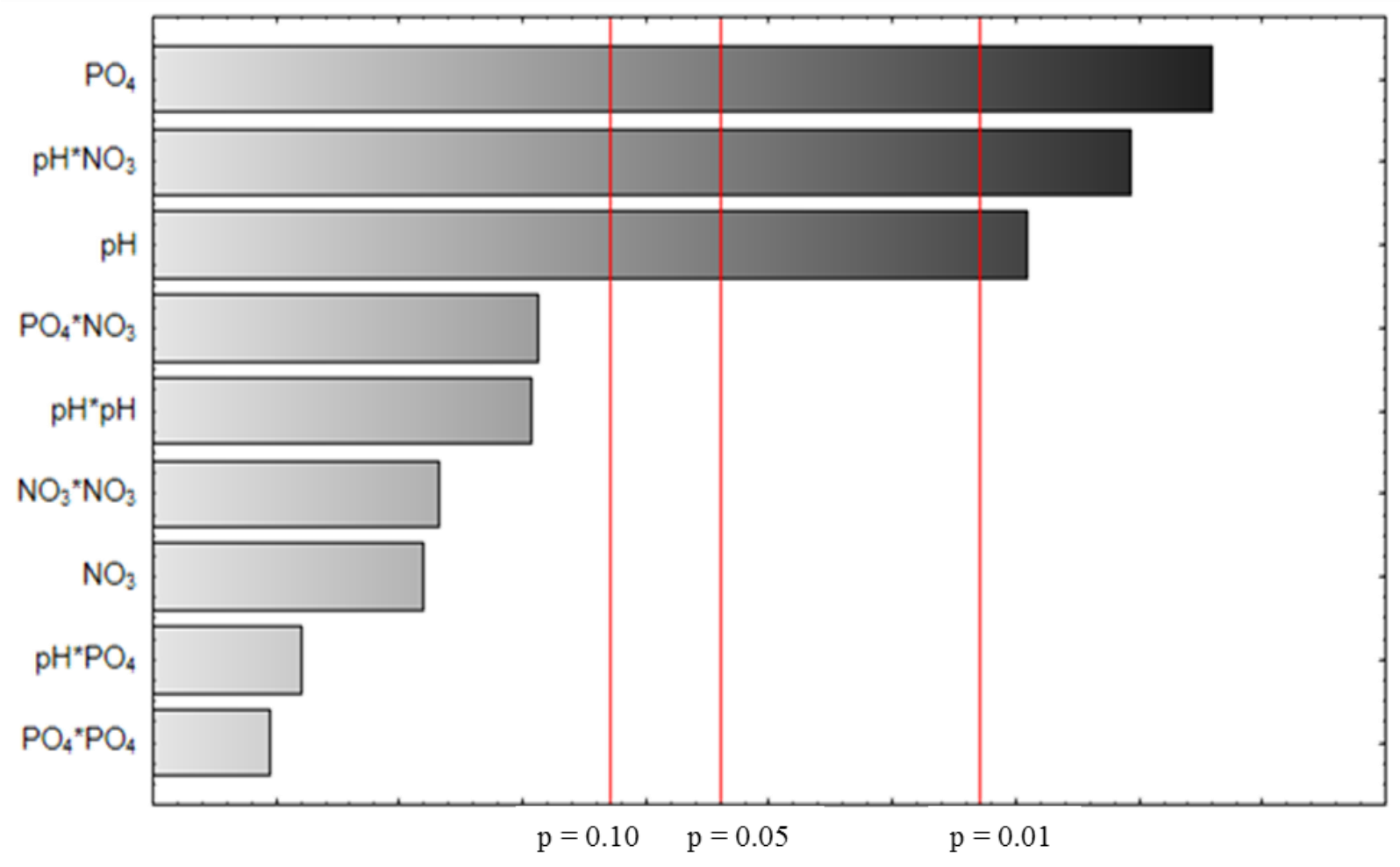

(a)

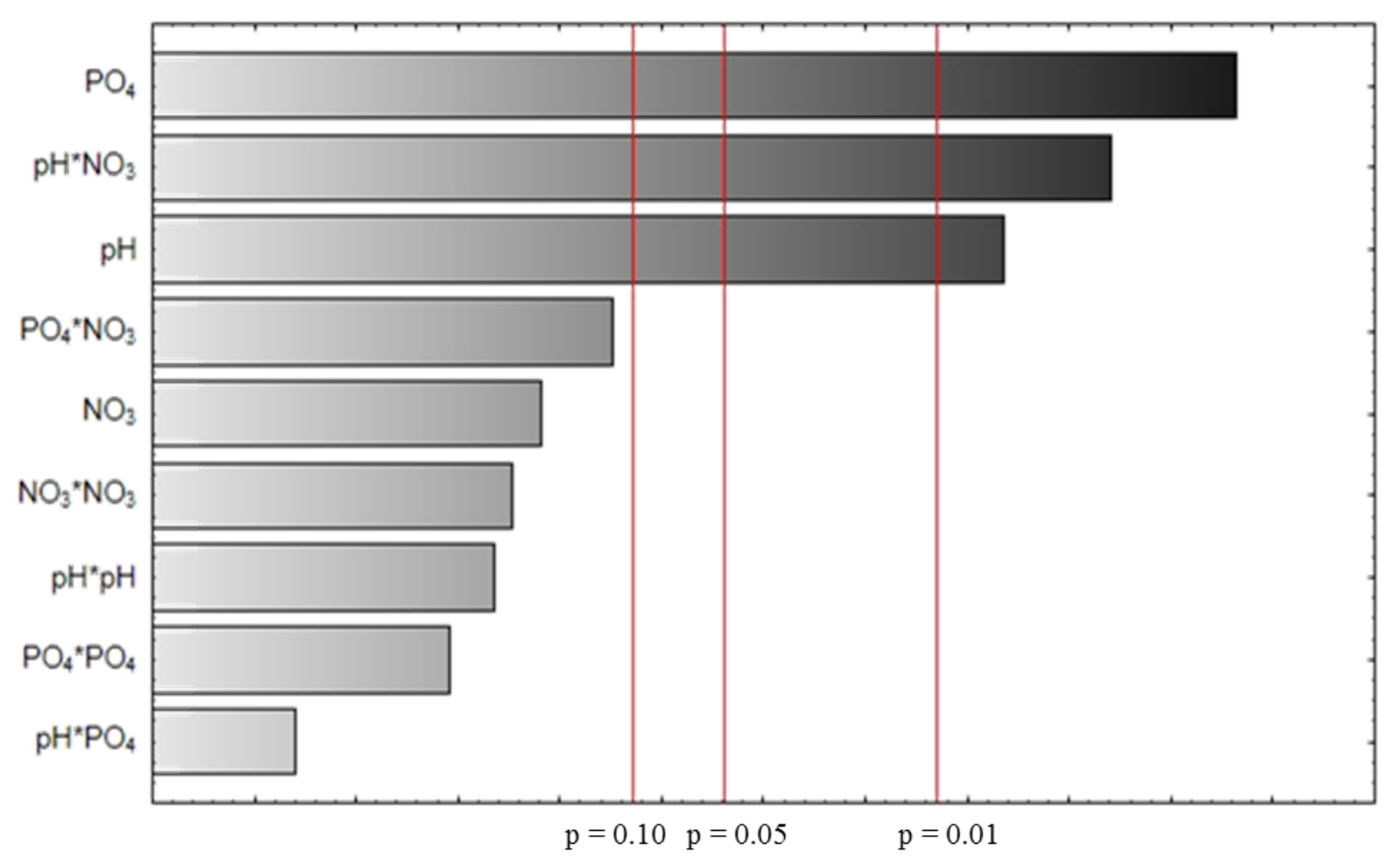

(b)

FIGURE 1. Pareto charts at 1, 5, and $10 \%$ significance levels for the independent variables $\mathrm{pH}$, nitrate, and phosphate including linear and quadratic effects and interactions for efficiency of fluoride removal as the variable response without transformation (a) and with square root transformation (b).

The main effect of the variables $\mathrm{pH}$ and phosphate and the interaction of $\mathrm{pH}$ with nitrate were significant at 10,5 , and $1 \%$ levels for fluoride removal efficiency with and without transformation. Terms with less significance were removed in order to obtain the best model within the evaluated experimental region, considering the modeling hierarchy. Thus, the most adjusted/indicated equations for three models are shown in Table 3 and their respective quality of fit data are shown in Table 4. 
TABLE 3. Equations obtained after regression analysis.

\begin{tabular}{cl}
\hline Model & \multicolumn{1}{c}{ Equation } \\
\hline 1 & $\varepsilon=70.40-13.55[\mathrm{pH}]+0.19\left[\mathrm{PO}_{4}\right]-0.11\left[\mathrm{NO}_{3}\right]+0.77[\mathrm{pH}]^{2}+0.000015\left[\mathrm{PO}_{4}\right]^{2}+0.012\left[\mathrm{pH}^{*} \mathrm{NO}_{3}\right]+0.0018\left[\mathrm{PO}_{4} * \mathrm{NO}_{3}\right]$ \\
2 & $\varepsilon=28.13-2.19[\mathrm{pH}]+0.92\left[\mathrm{PO}_{4}\right]-0.085\left[\mathrm{NO}_{3}\right]+0.012\left[\mathrm{pH} * \mathrm{NO}_{3}\right]$ \\
3 & $\varepsilon^{0,5}=5.86-0.42[\mathrm{pH}]+0.15\left[\mathrm{PO}_{4}\right]-0.013\left[\mathrm{NO}_{3}\right]+0.0018\left[\mathrm{pH}^{*} \mathrm{NO}_{3}\right]$ \\
\hline
\end{tabular}

TABLE 4. Quality predictors of the obtained models.

\begin{tabular}{lccc}
\hline Model & $\mathbf{1}$ & $\mathbf{2}$ & $\mathbf{3}$ \\
\hline Optimal predicted (\%) & 36.38 & 28.72 & 34.78 \\
$\mathrm{R}^{2}$ & 0.86 & 0.76 & 0.78 \\
$\mathrm{R}^{2}$ adjusted & 0.76 & 0.69 & 0.72 \\
$\mathrm{R}^{2}$ predicted & 0.35 & 0.50 & 0.53 \\
$\mathrm{AP}$ & 13.14 & 12.50 & 13.07 \\
$\mathrm{~S}$ & 2.18 & 2.52 & 0.37 \\
Fcalc/Ftab5 & 2.88 & 3.30 & 3.68 \\
\hline
\end{tabular}

AP: Adequate precision; S: Standard error of the regression; Fcalc/Ftab5: ratio between calculated F (regression) and tabulated F $(5 \%)$.

Model 3 was chosen considering the data shown in Table 4, as it combines higher simplicity with good adjustment indicators: adequate precision higher than 4.00 and difference between $\mathrm{R}^{2}$ adjusted and $\mathrm{R}^{2}$ predicted lower than 0.20 . The maximum expected efficiency value for all three models is obtained at points of $\mathrm{pH} 9$, phosphate equal to $10 \mathrm{mg} \mathrm{L}^{-1}$, and nitrate equal to 800 $\mathrm{mg} \mathrm{L}^{-1}$. Table 5 shows the analysis of variance for model 3, in which the main effect of nitrate was not significant at the $5 \%$ level, but $\mathrm{pH}$, phosphate, and the interaction between $\mathrm{pH}$ and nitrate showed significance. Furthermore, the p-value of the lack of fit was higher than the significance level, indicating no evidence that the model does not fit the observations.

TABLE 5. Analysis of variance of the chosen regression model (transformed response) considering a 5\% significance level.

\begin{tabular}{lccccc}
\hline Source of variation & DF & Sum of squares (Adj.) & Mean square (Adj.) & Calculated F & p-value \\
\hline Model & 4 & 6.2661 & 1.56652 & 11.70 & $<0.001$ \\
Linear & 3 & 4.2960 & 1.43201 & 10.70 & 0.001 \\
pH & 1 & 1.5012 & 1.50119 & 11.21 & 0.005 \\
Phosphate & 1 & 2.5825 & 2.58255 & 19.29 & 0.001 \\
Nitrate & 1 & 0.2123 & 0.21228 & 1.59 & 0.230 \\
Interaction with 2 factors & 1 & 1.9659 & 1.96586 & 14.68 & 0.002 \\
pH*nitrate & 1 & 1.9659 & 1.96586 & 14.68 & 0.002 \\
Error & 13 & 1.7405 & 0.13388 & & \\
Lack of fit & 10 & 1.6400 & 0.16400 & 4.89 & 0.109 \\
Pure error & 3 & 0.1005 & 0.03350 & $*$ & $*$ \\
Total & 17 & 8.0065 & & & \\
\hline
\end{tabular}

The maximum expected removal was $34.78 \%$ under the mentioned optimal conditions, with a maximum desirability value (1.00), considering as a goal maximizing the removal value. However, the same desirability was also obtained under acidic conditions, with a predicted removal of $27.03 \%$ for $\mathrm{pH}$
$5,10 \mathrm{mg} \mathrm{L}^{-1}$ of phosphate, and absence of nitrate. Despite this, the promising observed and predicted removals occurred in alkaline conditions, as shown in the contour plots presented in Figure 2. The third variable has always been maintained at the optimal fixed level predicted by model 3 . 

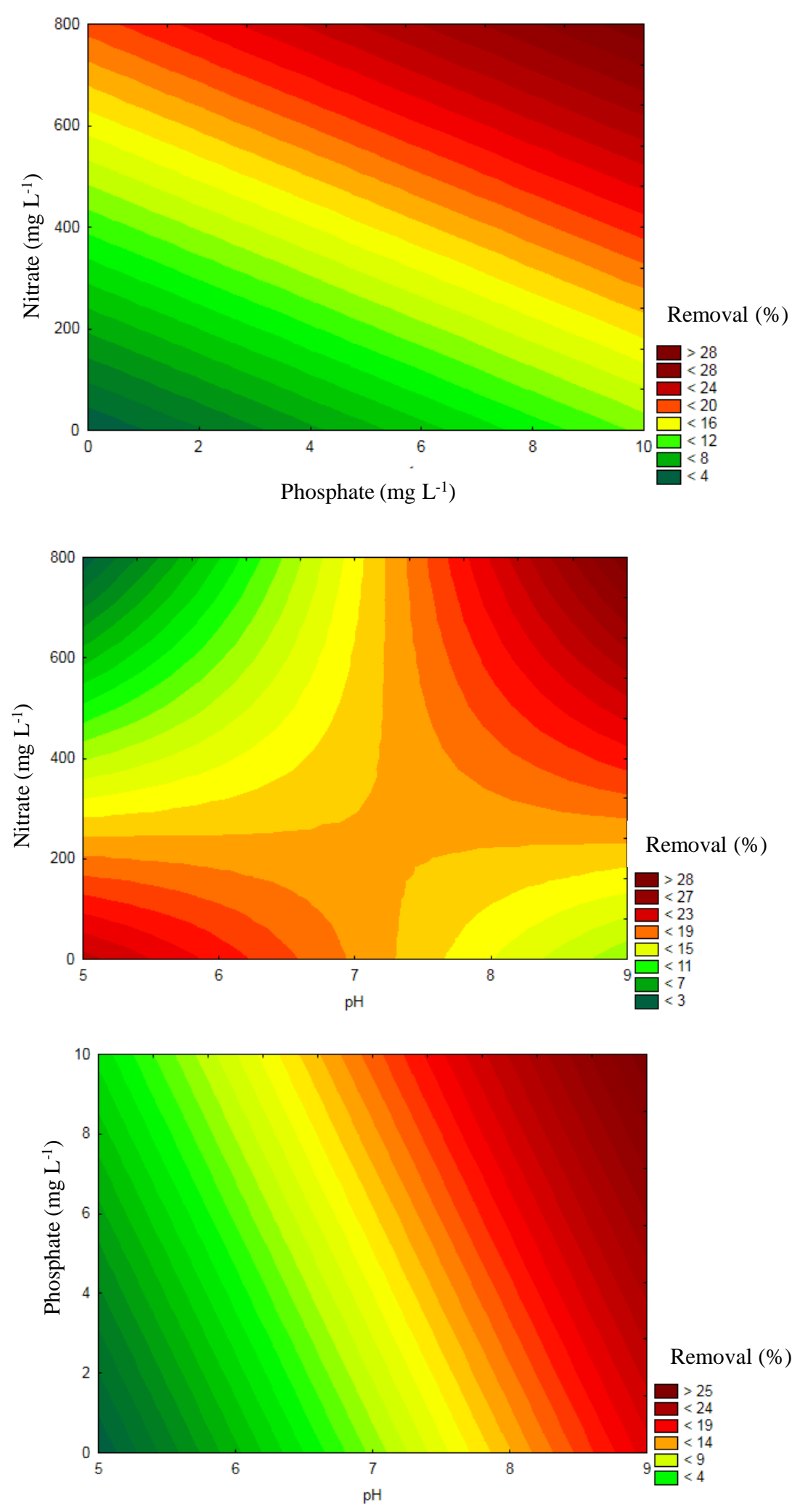

FIGURE 2. Contour plots relating the concentrations of the variables under study to the response variable.

Figure 2 shows that the highest removal efficiency of fluoride mass from water occurred in an alkaline conditions and at the upper extremes of the phosphate and nitrate concentrations. Despite the fitting and prediction indicators (AP and difference between $\mathrm{R}^{2}$ adjusted and $\mathrm{R}^{2}$ predicted), inferences about the predictive capacity of the chosen model should be made carefully, as the optimal is in the extreme region, as $+\alpha,+\alpha,+\alpha$.
Absorption by roots occurs by diffusion through the cell membrane. Although both forms ( $\mathrm{HF}$ and $\mathrm{F}^{-}$) coexist at $\mathrm{pH}$ close to 9 , the predominant form of fluorine is $\mathrm{F}^{-}$, which has its uptake favored by the strong ion electronegativity and its small ionic radius. Karmakar et al. (2018) investigated fluoride absorption by Pistia stratiotes, family Araceae as L. punctata, and observed that the absorption would be favored in acidic conditions, with a $\mathrm{pH}$ of about 5.5. However, no 
statistical difference was observed between treatments ( $\mathrm{pH}$ values of 5.5, 6.5, 7.5, and 8.5). On the other hand, Stevens et al. (2000) suggested that the high HF activity in an acidic medium $(\mathrm{pH}<3.6)$ would favor absorption and fluorine would be in the form of $\mathrm{F}^{-}$in a basic medium ( $\mathrm{pH}$ 7 9), showing the potential to be absorbed, especially at high relative concentrations.

The data also showed that the removal of fluoride from the aqueous environment was favored when phosphate and nitrate concentrations in the solution were the maximum among those tested. Stevens et al. (1998) argued that there is no competition between fluorine absorption by plants and phosphate and nitrate anions. These anions are also not correlated in absorption by plants, but their limitation could affect their growth (Buwalda \& Warmenhoven, 1999). The appropriated supply of macronutrients, phosphate, and nitrate benefits the good development and growth of plants. Plant growth contributes to increased transpiration; the higher the transpiration, the higher the water uptake (Ren et al., 2015) and, consequently, the higher the fluoride absorption, considering that fluoride passively enters the plant (Xian-chen et al., 2013). Banerjee \& Roychoudhury (2019) stated that metabolomic studies should be exhaustively carried out to better understand the routes of fluorine absorption and transport in plant species.

The initial and final wet mass of L. punctata plants showed an increase in plant biomass in all tests, with no significant difference from each other. An average increase of $66.7 \%$ was observed in the wet mass, while the average dry mass of all treatments was $0.29 \mathrm{~g}$.

No studies were found using the species $L$. punctata for phytoremediation of fluoridecontaminated waters, but this plant has been used for remediating other cationic and anionic contaminants, with satisfactory results. Guo et al. (2017) analyzed the potential of the species to mitigate cobalt and nickel in water and found removal efficiencies of 58.6 and $56.2 \%$, respectively. Miranda et al. (2020) report this species had nutrient uptakes of 74,43 , and $94 \%$ of ammonium, phosphate, and nitrate, respectively, in an environment with $0.4 \mathrm{mg} \mathrm{L}^{-1}$ of $\mathrm{SeO} 2$ after 5 days of exposure. Canatto et al. (2021) considered L. punctata as a hyperaccumulating species of arsenate after observing the tolerance indices relative to different levels of this contaminant. Ertekin et al. (2015) also indicated the species for phytoremediation of water contaminated with hydrocarbons from petroleum.

Other species used in the phytoremediation of fluoride-contaminated waters have been investigated by several authors. Diaz \& Pedraza (2010) assessed the fluoride (4 $\left.\mathrm{mg} \mathrm{L}^{-1}\right)$ removal of Camellia japonica, Pittosporum tobira, and Saccharum officinarum observing efficiencies ranging from 7.5 to $40 \%$. Karmakar et al. (2016) investigated the efficiency of the aquatic species Pistia stratiotes, Eichhornia crassipes, and Spirodela polyrhiza in removing fluoride at the initial concentration of $5 \mathrm{mg} \mathrm{L}^{-1}$, same concentration and time interval tested here, and obtained results of $15.4,17.7$, and $9.8 \%$, respectively.
The efficiencies found here are of the same magnitude, with an average of $12.1 \%$ and a maximum of $21.0 \%$.

The species L. punctata has great potential for fluoride phytoremediation, but further investigations on the phytotoxic concentration that the species tolerates without damage, are still necessary as well as the factors that influence the absorption rates.

\section{CONCLUSIONS}

Landoltia punctata showed phytoremediation potential for the tested conditions of initial fluoride concentration of $5 \mathrm{mg} \mathrm{L}^{-1}, \mathrm{pH}$ ranging from 5 to 9 , and phosphate and nitrate concentration ranging from 0 to $10 \mathrm{mg} \mathrm{L}^{-1}$ and 0 to $800 \mathrm{mg} \mathrm{L}^{-1}$, respectively.

The maximum tested levels of phosphate and nitrate concentrations and $\mathrm{pH} 9$ were the conditions that favored the highest removal of fluoride from the solution. Fluoride removal from the solution was attributed to its absorption by $L$. punctata plants although some $\mathrm{F}$ precipitation may have contributed to the observed values. Thus, the species achieved a maximum fluoride removal efficiency of $21.0 \%$ and an average efficiency of $12.1 \%$. The species also showed good growth rates and an average increase of $66.7 \%$ in biomass (wet basis).

Moreover, further studies on the intervening factors and tested ranges are necessary for a better understanding as to whether the fluoride absorption by plants is favored, including other concentrations of this contaminant.

\section{ACKNOWLEDGEMENTS}

This work was funded by Minas Gerais Research Foundation (FAPEMIG PPM-00911-15) and Coordination for the Improvement of Higher Education Personnel (CAPES Finance Code 001). We also thank to STTA for their translation services and Eng. Edinei José Araújo Martins for his helping during laboratory analyses.

\section{REFERENCES}

Abouleish MYZ (2016) Evaluation of fluoride levels in bottled water and their contribution to health and teeth problems in the United Arab Emirates. Saudi Dental Journal 28(4): 194-202. DOI: https://doi.org/10.1016/j.sdentj.2016.08.002

APHA (2017) Standard methods for the examination of water and wastewater. $23^{\text {rd }}$ Edition. Washington, D.C: American Public Health Association, American Water Works Association, Water Environment Federation.

Banerjee A (2015) Groundwater fluoride contamination: A reappraisal. Geoscience Frontiers 6(2): 277-284. DOI: https://doi.org/10.1016/j.gsf.2014.03.003

Banerjee A, Roychoudhury A (2019) Fluorine: A biohazardous agent for plants and phytoremediation strategies for its removal from the environment. Biologia Plantarum 63(1): 104-112. DOI: https://doi.org/10.32615/bp.2019.013 
Barathi M, Kumar ASK, Rajesh N (2019) Impact of fluoride in potable water - An outlook on the existing defluoridation strategies and the road ahead.

Coordination Chemistry Reviews 387: 121-128. DOI: https://doi.org/10.1016/j.ccr.2019.02.006

Baunthiyal M, Ranghar S (2014) Physiological and biochemical responses of plants under fluoride stress: an overview. Fluoride 47(4): 287-293.

Buwalda F, Warmenhoven M. (1999) Growth-limiting phosphate nutrition suppresses nitrate accumulation in greenhouse lettuce. Journal of Experimental Botany 50(335): 813-821. DOI:

https://doi.org/10.1093/jxb/50.335.813

Canatto RA, Oliveira JA de, Silva CJ da, Albino BES (2021) Tolerance of Landoltia punctata to arsenate: an evaluation of the potential use in phytoremediation programs. International Journal of Phytoremediation 23(1): 102-110. DOI:

https://doi.org/10.1080/15226514.2020.1797630

Clark RB (1975) Characterization of phosphatase of intact maize roots. Journal of Agricultural and Food Chemistry 23: 458-460. DOI: https://doi.org/10.1021/jf60199a002

Díaz MSS, Pedraza CZ (2010). Fluoride removal from water by plant species that are tolerant and highly tolerant to hydrogen fluoride. Fluoride 43(2): 150-156.

Dubchak S, Bondar O (2018) Bioremediation and phytoremediation: Best approach for rehabilitation of soils for future use. Remediation Measures for Radioactively Contaminated Areas: 201-221. DOI: https://doi.org/10.1007/978-3-319-73398-2_9

Ertekin Ö, Kösesakal T, Ünlü VS, Dağli S, Pelitli V, Uzyol H, Tuna Y, Külen O, Yüksel B, Onarici S, Keskin BC, Memon A (2015) Phytoremediation potential of Landoltia punctata on petroleum hydrocarbons. Turkish Journal of Botany 39(1): 23-29. DOI: https://doi.org/10.3906/bot-1403-42

Ghaderpoori M, Paydar M, Zarei A, Alidadi H, Najafpoor AA, Gohary AH, Shams M (2018). Health risk assessment of fluoride in water distribution network of Mashhad, Iran. Human and Ecological Risk Assessment: 1-12. DOI: https://doi.org/10.1080/10807039.2018.1453297

Guo L, Ding Y, Xu Y, Li Z, Jin Y, He K, Fang Y, Zhao H (2017) Responses of Landoltia punctata to cobalt and nickel: Removal, growth, photosynthesis, antioxidant system and starch metabolism. Aquatic Toxicology 190: 87-93. DOI: https://doi.org/10.1016/j.aquatox.2017.06.024

Ikeura H, Kawasaki Y, Kaimi E, Nishiwaki J, Noborio K, Tamaki M (2016) Screening of plants for phytoremediation of oil-contaminated soil. International Journal of Phytoremediation 18(5): 460-466. DOI: https://doi.org/10.1080/15226514.2015.1115957
Kanduti D, Sterbenk P, Artnik B (2016) Fluoride: a Review of Use and Effects on Health. Mater Sociomed 28(2): 133-137. DOI:

https://doi.org/10.5455/msm.2016.28.133-137

Karmakar S, Mukherjee J, Mukherjee S (2016). Removal of fluoride contamination in water by three aquatic plants. International Journal of Phytoremediation 18(3): 222-227. DOI: https://doi.org/10.1080/15226514.2015.1073676

Karmakar S, Mukherjee J, Mukherjee S (2018) Biosorption of fluoride by water lettuce (Pistia stratiotes) from contaminated water. International Journal of Environmental Science and Technology 15(4): 801-810. DOI: https://doi.org/10.1007/s13762$017-1439-3$

Khandare RV, Desai SB, Bhujbal SS, Watharkar AD, Biradar SP, Pawar PK, Govindwar SP (2017)

Phytoremediation of fluoride with garden ornamentals Nerium oleander, Portulaca oleracea, and Pogonatherum crinitum. Environmental Science and Pollution Research 24(7): 6833-6839. DOI: https://doi.org/10.1007/s11356-017-8424-8

Kim YS, Lee YH, An B, Choi SA, Park JH, Jurng JS, Lee SH, Choi JW (2012). Simultaneous removal of phosphate and nitrate in wastewater using highcapacity anion-exchange resin. Water, Air, and Soil Pollution 223(9): 5959-5966. DOI: https://doi.org/10.1007/s11270-012-1331-1

Linkohr BI, Williamson LC, Fitter AH, Leyser HMO (2002) Nitrate and phosphate availability and distribution have different effects on root system architecture of Arabidopsis. Plant Journal 29(6): 751760. DOI: https://doi.org/10.1046/j.1365313X.2002.01251.X

Mantai KE, Newton ME (1982) Root growth in Myriophyllum: a specific plant response to nutrient availability? Aquatic Botany 13(C): 45-55. DOI: https://doi.org/10.1016/0304-3770(82)90039-0

Mateus NB, Barbin D, Conagin A (2008) Viabilidade de uso do delineamento composto central. Acta Scientiarum. Technology 23: 1537-1546. DOI: https://doi.org/10.4025/actascitechnol.v23i0.2795

Ministry of Health / Ministério da Saúde. Secretaria de Vigilância em Saúde. Boletim Epidemiológico vol.46 no 29/2015 Reemergência da Febre Amarela Silvestre no Brasil, 2014/2015: Situação epidemiológica e a importância da vacinação preventiva e da vigilância intensificada no período sazonal. Brasília: Ministério da Saúde, 2015.

Miranda AF, Kumar NR, Spangenberg G, Subudhi S, Lal B, Mouradov A (2020) Aquatic Plants, Landoltia punctata, and Azolla filiculoides as Bio-Converters of Wastewater to Biofuel. Plants 9(4): 437. DOI: https://doi.org/10.3390/plants9040437

Murphy JAMES, Riley JP (1962) A modified single solution method for the determination of phosphate in natural waters. Analytica Chimica Acta 27: 31-36. DOI: https://doi.org/10.1016/S0003-2670(00)88444-5 
Nie X, Dong F, Bian L, Liu M, Ding C, He H, Yang G, Sun S, Qin Y, Huang R, Li Z, Wei R, Wang L (2017) Uranium binding on landoltia punctata as a result of formation of insoluble nano-U (VI) and U (IV) phosphate minerals. ACS Sustainable Chemistry and Engineering 5(2): 1494-1502. DOI:

https://doi.org/10.1021/acssuschemeng.6b02109

Pereira SDF, Pott VJ, Temponi LG (2016) Lemnoideae (Araceae) no estado do Paraná, Brasil. Rodriguésia 67(3): 839-848. DOI: https://doi.org/10.1590/21757860201667321

Qasemi M, Afsharnia M, Zarei A, Farhang M (2019) Human and Ecological Risk Assessment: An International Non-carcinogenic risk assessment to human health due to intake of fluoride in the groundwater in rural areas of Gonabad and Bajestan , Iran : A case study. Human and Ecological Risk Assessment: 1-12. DOI: https://doi.org/10.1080/10807039.2018.1461553

Ren B, Wang M, Chen Y, Sun G, Li Y, Shen Q, Guo S (2015) Water absorption is affected by the nitrogen supply to rice plants. Plant and Soil 396(1-2): 397-410. DOI: https://doi.org/10.1007/s11104-015-2603-5

Ruan J, Ma L, Shi Y, Han W (2004) The impact of pH and calcium on the uptake of fluoride by tea plants (Camellia sinensis L.). Annals of Botany 93(1): 97105. DOI: https://doi.org/10.1093/aob/mch010

Sari, GT, Tovo, MF, Feldens, EG, Faraco Junior, IM (2010) Fluorose dentária no Brasil: Quadro epidemiológico atual. Revista Íbero-americana de Odontopediatria \& Odontologia de Bebê, 7(38).

Singh G, Kumari B, Sinam G, Kriti KN, Mallick S (2018) Fluoride distribution and contamination in the water, soil and plants continuum and its remedial technologies, an Indian perspective- a review. Environmental Pollution 239: 95-108. DOI: https://doi.org/10.1016/j.envpol.2018.04.002

Singh J, Singh P, Singh A (2016) Fluoride ions vs removal technologies: A study. Arabian Journal of Chemistry 9(6): 815-824. DOI:

https://doi.org/10.1016/j.arabjc.2014.06.005

Sinha S, Saxena R, Singh S (2000) Fluoride removal from water by Hydrilla verticillata (l.f.) Royle and its toxic effects. Bulletin of Environmental Contamination and Toxicology 65(5): 683-690. DOI: https://doi.org/10.1007/s001280000177
Sokolova LG, Zorina SY, Belousova EN (2019) Zonal cultivars of field crops as a reserve for the phytoremediation of fluorides polluted soils. International Journal of Phytoremediation 21(6): 577 582. DOI: https://doi.org/10.1080/15226514.2018.1540545

Stegemeier JP, Colman BP, Schwab F, Wiesner MR, Lowry GV (2017) Uptake and Distribution of Silver in the Aquatic Plant Landoltia punctata (Duckweed) Exposed to Silver and Silver Sulfide Nanoparticles. Environmental Science and Technology 51(9): 49364943. DOI: https://doi.org/10.1021/acs.est.6b06491

Štepec D, Ponikvar-svet M (2019) Fluoride in Human Health and Nutrition. Acta Chimica Slovenica 66(2): 255-275. DOI: https://doi.org/10.17344/acsi.2019.4932

Stevens DP, McLaughlin MJ, Alston AM (1998) Phytotoxicity of the fluoride ion and its uptake from solution culture by Avena sativa and Lycopersicon esculentum. Plant and Soil 200(2): 119-129. DOI: https://doi.org/10.1023/A:1004392801938

Stevens DP, Mclaughlin MJ, Randall PJ,

Keerthisinghe G (2000) Effect of fluoride supply on fluoride concentrations in five pasture species: Levels required to reach phytotoxic or potentially zootoxic concentrations in plant tissue. Plant and Soil 227(1-2): 223-233. DOI: https://doi.org/10.1023/A:1026523031815

Weerasooriyagedara M, Ashiq A, Rajapaksha AU, Wanigathunge RP, Agarwal T, Magana-Arachchi D, Vithanage M (2020) Phytoremediation of fluoride from the environmental matrices: A review on its application strategies. Groundwater for Sustainable Development, 10: 100349. DOI:

https://doi.org/10.1016/j.gsd.2020.100349

Xian-chen Z, Hong-jian G, Zheng-zhu Z, Xiao-chun W (2013) Influences of different ion channel inhibitors on the absorption of fluoride in tea plants (Camellia sinesis L.). Plant Growth Regulation 69(1): 99-106. DOI: https://doi.org/10.1007/s10725-012-9751-X

Yadav M, Kumari N, Sharma V (2018)

Phytoremediation efficiency of Brassica juncea cultivars at vegetative and reproductive growth stages under individual and combined treatment of fluoride and aluminium. International Journal of Phytoremediation 20(9): 922-929. DOI: https://doi.org/10.1080/15226514.2018.1448361 